\title{
Betta splendens: A territorial note
}

\author{
PAUL M. BRONSTEIN \\ Trenton State College, Trenton, New Jersey 08625
}

\begin{abstract}
Two communities of Siamese fighting fish were observed, each for about 4 months. Males occasionally built nests, and these structures were always located in corners. Consistent with Goldstein's (1975) report, male Bettas chose isolated areas for nest building and spawning.
\end{abstract}

This paper is a brief report appended to a set of studies concerned with the style and function of aggression in male Siamese fighting fish (Betta splendens) (Bronstein, in press). In that longer article, I showed, first, that bettas build nests against vertical surfaces, with crevices and corners more preferred than flat walls. Second, it was demonstrated that nests were constructed far from male competitors. Third, exposure to a male challenger led nest builders to fixate on and enlarge their nests.

These individual behaviors suggest a strategy whereby animals disperse and segregate themselves as a preface to reproductive activity. Taken together, these elements seem to be components of territorial defense, and Goldstein (1975) reported one instance of such a social structure in laboratory-housed bettas. The current report is a description of nest building in group-living bettas, with Goldstein's findings generally replicated.

\section{DEMONSTRATION 1}

\section{Method}

Subjects were five adult bettas (one male and four females), purchased locally, that had previously been used for breeding while housed with an opposite-sex conspecific in 15-20 liters of water for at least 1 week. Following the separation of breeding pairs (between January 13 and February 15, 1980), fish were housed in 190 liters of water in an all-glass rectangular aquarium (150 cm long, $43.2 \mathrm{~cm}$ wide) that had $2 \mathrm{~cm}$ of undyed gravel as flooring. The tank had nine white plastic dividers, five on one long wall and four on the opposite long wall. Dividers $(.25 \mathrm{~mm}$ thick) were glued perpendicular to these walls, extended $22.9 \mathrm{~cm}$ into the tank, and were perforated with holes $(1 \mathrm{~mm}$ in diameter, 5 holes $\left(\mathrm{cm}^{2}\right)$. Adjacent dividers extended from opposite walls and were separated by $15.2 \mathrm{~cm}$.

For the 1st month of group housing, other fish (both males and females) were periodically added to and removed from the aquarium. Maximum density was 12 animals. However, beginning on February 15, 1980, the five subjects remained together with no further intrusions. Fish were maintained in aged tap water $(\mathrm{pH}=7.0)$ at $27^{\circ} \mathrm{C}-28^{\circ} \mathrm{C}$, with overhead lights turned on at 0800 and shut off at $2200 \mathrm{~h}$. Feedings of either live or frozen brine shrimp (Artemia salina) or dry food (Wardleys) occurred

This paper was supported by grants from the faculty at Trenton State College as well as by Grant MH 33389-01 from the National Institute of Mental Health. Requests for reprints should be sent to Paul M. Bronstein, Department of Psychology, Box 940, Trenton State College, Hillwood Lakes Campus, Trenton, New Jersey 08625 . twice daily (1000 and $1600 \mathrm{~h}$ ). During feedings, the existence and location of nests, along with subjects' positions with regard to any nests, were recorded.

\section{Results}

On May 7, 1980, the male was found with a bubble nest in an external corner of the tank. The male, now observed for $10 \mathrm{~min} /$ feeding, located himself beneath the nest almost exclusively, and this nest fixation persisted through May 9 . He left the nest only briefly and then only when in immediate pursuit of females. During these $72 \mathrm{~h}$, the male spawned with two of the females, one at a time, near his nest. Eggs were collected and pushed into the nest by the male, but no hatchlings were ever seen. During this nest-building episode, there was an unquantified but obvious increase in agonistic encounters (biting and chasing) among the previously docile females. One female was killed during this period. The nest persisted for 4 subsequent days, although nest building and nest fixation by the male were no longer seen. Spawning and agonistic encounters among females were not detected during this 4-day period.

\section{DEMONSTRATION 2}

\section{Method}

Subjects were one male and eight female bettas, siblings that hatched on April 4, 1980, from eggs resulting from one spawning. These fry, along with about 200 of their siblings, were housed en masse in 65 liters of water and fed freshly hatched brine shrimp several times daily. On May 22, 1980, 40 unsexed fry were placed in the tank used for the first demonstration and treated as in Demonstration 1. There were six stalks of elodea floating on the water surface, and the tank had been cleaned and refilled with aged tap water not contaminated by any fish before the start of this second group of observations.

\section{Results}

When housed as a group of more than 200 , the fish exhibited very little biting. However, chasing and biting became pronounced among the subgroup of transferees within minutes of their being shifted by net to the larger tank. On June 23, only one male and eight females remained alive. By contrast, the group-housed fry from which these nine fish were collected remained together with some biting and, hence, fin damage, but with no deaths.

On August 14, 1980, the male constructed a nest at 
an intersection of a plastic barrier and a glass wall. Nest remnants persisted for 3 days; however, there was no observable attachment to this collection of bubbles. On September 8, 1980, a second nest, also located at a wall-barrier intersection, was built. The male, now observed for $10 \mathrm{~min} /$ feeding, spent $100 \%$ of each observation beneath its nest. No spawning, chasing, or biting was noted.

\section{GENERAL DISCUSSION}

All observations of nest building were consistent with the hypothesis that males choose relatively isolated crevices for those structures. However, the current results further complicate the task of an experimenter in defining a nest. Bronstein (in press) showed that collections of bubbles so few in number as to usually be overlooked by people were the sites of attachment and further nest building once an opponent male was presented to a resident. The current report includes instances in which nests that would be easily recognized by experimenters were, nonetheless, not sites to which animals became attached. The use of nests by the fish obviously depends not just upon the existence of the structure itself, but also upon the interactions of nest building with other behaviors or conditions.

Demonstration 2 suggests two further points worthy of analysis. First, nest building matured prior to nest-defense actions. Second, social structure was altered by a change in environmental design. Fighting occurred when space was available. However, when fish remained crowded together from the time of hatching, they adjusted to the lack of defensible space by maintaining themselves in relatively nonaggressive schools.

\section{REFERENCES}

Bronstein, P. M. Commitments to aggression and to nest sites in male Betta splendens. Journal of Comparative and Physiological Psychology, in press.

Goldstein, S. R. Observations on the establishment of a stable community of adult male and female Siamese fighting fish (Betta splendens). Animal Behavior, 1975, 23, 179-185.

(Received for publication November 19, 1980.) 